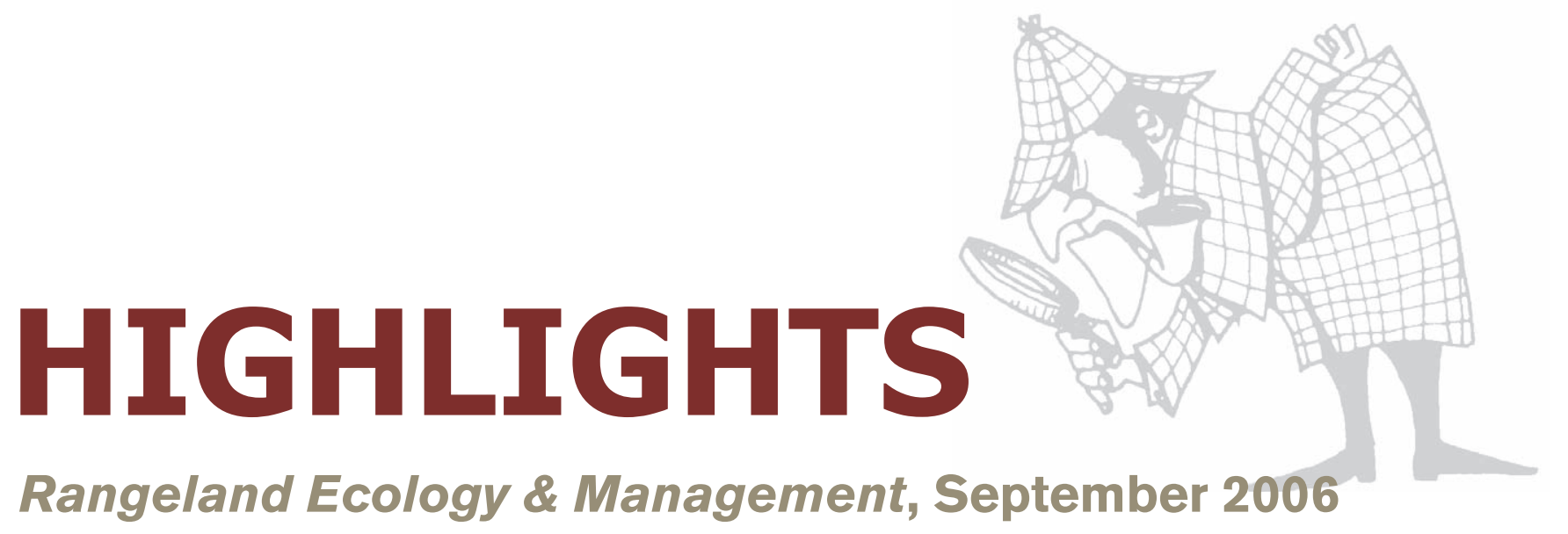

\section{Biological Control of Leafy Spurge: Utilization and Implementation}

Nancy M. Hodur, F. Larry Leistritz, and

Dean A. Bangsund

Leafy spurge is an exotic, noxious, perennial weed that is widely established in the north-central United States. A research and demonstration project, TEAM Leafy Spurge, was initiated to develop and demonstrate ecologically based strategies that can produce effective, affordable leafy spurge control. To assess the effectiveness of current and perceived control of leafy spurge due to biological control agents, a mail survey was sent to 468 people. Respondents reported basic information about the number and characteristics of release sites, characteristics of the leafy spurge stands, as well as the level of control to date and perceived level of eventual control.

\section{Efficacy of Flea Beetle Control of Leafy Spurge in Montana and South Dakota}

Jack L. Butler, Matthew S. Parker, and John T. Murphy

Leafy spurge (Euphorbia esula L.) is an aggressive exotic plant species that is now well established throughout much of the western United States and Canada. Information is needed that documents leafy spurge population dynamics in response to biological control and evaluates the response of the resident vegetation. Successful establishment of the biological control agents (flea beetles) occurred on a wide variety of grassland and shrubland sites, followed by significant reductions in density and cover of leafy spurge. Graminoid cover increased significantly following reductions in the dominance of leafy spurge, while forb cover changed very little throughout the study.

\section{Effect of Herbicides for Leafy Spurge Control on the Western Prairie Fringed Orchid}

\section{Ann M. Erickson, Rodney G. Lym, and Don Kirby}

Leafy spurge has invaded the habitat of the western prairie fringed orchid, a federally listed threatened species. Biologi- cal control has not worked in the orchid habitat, so research was initiated to evaluate the effects of imazapic and quinclorac, herbicides effective for the control of leafy spurge, on the survival and fecundity of the threatened orchid. Orchids treated with quinclorac regrew as vigorously and were as fecund as untreated orchids, whereas imazapic may have a negative effect on both plant population and flower production. Quinclorac will be a valuable tool to control leafy spurge in the habitat of the orchid and contribute to the recovery of this threatened species.

\section{Potential Impact of Two Aphthona spp. on a Native, Nontarget Euphorbia Species}

\section{Stefanie D. Wacker and Jack L. Butler}

There are inherent ecological risks associated with introducing foreign organisms into any ecosystem as biological control agents, even after the agents have been approved for release. We used the differences in ecological characteristics between the target species (leafy spurge) and a taxonomically closely related species to assess the potential for postrelease, nontarget impacts of biological control agents (flea beetles). We argue that ecological separation between target and nontarget species may be an important factor in reducing the potential of nontarget impacts. Further, we suggest that an evaluation of ecological separation may provide a more thorough prerelease assessment of biological control agents.

\section{Integrated Management of Leafy Spurge- Infested Rangeland}

James S. Jacobs, Roger L. Sheley, and John J. Borkowski

Leafy spurge is an invasive Eurasian weed on pastures and rangeland in North America, where it reduces grass forage production. Our objective was to determine the effects of multispecies grazing combined with Aphthona flea beetles on leafy spurge-infested rangeland. Grazing decreased vegetative stem density by $80 \%$ and flowering stems density by $95 \%$ over a 4 -year period. The decrease was more rapid when grazing was combined with Aphthona. Results suggest that 
combining multispecies grazing and Aphthona when restoring spurge-infested grasslands produces a synergistic effect.

\section{Evaluation of TEAM Leafy Spurge Project}

Nancy M. Hodur, F. Larry Leistritz, and

Dean A. Bangsund

In 1997, the Agricultural Research Service and Animal and Plant Health Inspection Service, U.S. Department of Agriculture, initiated a major project, TEAM Leafy Spurge (TLS), to develop and demonstrate ecologically based strategies for leafy spurge control. An initial survey of ranchers, local decision makers, and public land managers was conducted to evaluate factors that might affect the rate and extent of implementing various control strategies. In 2001, a second survey of the same population was conducted to determine if TLS met its objectives. The second survey indicated that TLS efforts had effectively addressed many of the constraints previously reported by landowners and land managers.

\section{Detection of Flowering Leafy Spurge With Satellite Multispectral Imagery}

\section{E. Raymond Hunt, Jr. and Amy E. Parker Williams}

The distribution and abundance of flowering leafy spurge (Euphorbia esula L.) can be determined with hyperspectral remote sensing, but the availability of hyperspectral sensors is limited. Hence, we tested the ability of Landsat 7 Enhanced Thematic Mapper Plus (ETM+), System Pour d'Observation de la Terre (SPOT) 4, and Airborne Visible Infrared Imaging Spectrometer (AVIRIS) to detect leafy spurge. The green/red band ratio was the vegetation index with the highest correlations to flowering leafy spurge cover, but the correlations were weak and not useful for predictions. Canopy reflectance modeling using the Scattering by Arbitrarily Inclined Leaves (SAIL) model suggests that the weak correlations were caused by variations in leaf area index.

\section{The Use of Landsat 7 Enhanced Thematic Mapper Plus for Mapping Leafy Spurge}

Carol S. Mladinich, Monica Ruiz Bustos, Susan Stitt, Ralph Root, Karl Brown, Gerald L. Anderson, and Steve Hager

To effectively manage leafy spurge at Theodore Roosevelt National Park, park managers need an image-based tool for landscape monitoring. As part of a larger project seeking the most appropriate tool for this purpose by evaluating several sensors with respect to their spatial and spectral properties, this paper explores the use of Landsat 7 ETM+ imagery to map leafy spurge. Landsat imagery is appropriate for mapping large stands of leafy spurge but does not detect small patches well. Pansharpened Landsat 7 (15-m spatial resolution) provided good accuracies, while the addition of the mid-infrared band 7 produced lower accuracies.

\section{Classification of Leafy Spurge With Earth Observing-1 Advanced Land Imager}

Susan Stitt, Ralph Root, Karl Brown, Steve Hager, Carol Mladinich, Gerald L. Anderson, Kathleen Dudek, Monica Ruiz Bustos, and Raymond Kokaly

This project was part of an effort to test and evaluate various sensors and analytical approaches to determine the most effective and cost-efficient method for mapping leafy spurge over large areas in support of managing or controlling this invasive species. This paper focuses on Earth Observing-1 Advanced Land Imager data. Overall accuracies derived from an unsupervised classification ranged from $59 \%$ to $66 \%$. This sensor-or one with a few additional spectral bands-could be useful for landscape scale mapping of leafy spurge, from which control measures could be based.

\section{Determining the Composition of Herbivore Diets in the Trans-Himalayan Rangelands: A Comparison of Field Methods}

\section{Rinjan Shrestha and Per Wegge}

Throughout the mountains of Central Asia, overgrazing by domestic livestock is considered a main threat to the native, wild ungulates. For multispecies management, better knowledge of the diets of the 2 animal groups is needed, based on standardized, suitable field methods. We compared 3 methods-microhistological analysis of feces (FA), bite counts (BC), and feeding site examination (FSE) - in domestic yak and small stock in high mountain ranges in Nepal. Results from FA compared closely with $\mathrm{BC}$, whereas those from FSE were more biased. The $\mathrm{BC}$ method cannot be used on wild species. Although more costly than FSE, FA is recommended because it gives more reliable information, but correction factors are needed because of differential digestion.

\section{Spatial Modeling of Biological Soil Crusts to Support Rangeland Assessment and Monitoring}

\section{Matthew A. Bowker, Jayne Belnap, and Mark E. Miller}

Biological soil crusts are a diverse soil surface community, prevalent in semiarid regions. We sampled low-disturbance sites in Grand Staircase-Escalante National Monument, Utah, to determine the feasibility of modeling the potential cover and composition of biological soil crusts in a large area. We used classification and regression trees to model cover of 4 crust types and 1 cyanobacterial biomass proxy. These models provide the necessary reference conditions to facilitate the comparison between the actual cover and composition of biological soil crusts at a given site and their potential cover and composition condition. 


\section{Remote Sensing for Grassland Management in the Arid Southwest}

Robert C. Marsett, Jiaguo Qi, Philip Heilman, Sharon H. Biedenbender, M. Carolyn Watson, Saud Amer, Mark Weltz, David Goodrich, and Roseann Marsett

We surveyed a group of rangeland managers in the Southwest about vegetation monitoring needs on grassland and semidesert grasslands. Based on their responses, the objective of the Rangeland Analysis Utilizing Geospatial Information Science (RANGES) project was to develop accurate conversion of remotely sensed data (satellite imagery) to quantitative estimates of total (green and senescent) standing cover and biomass. The ground reconnaissance protocol and image processing techniques together offer land managers accurate and timely methods for monitoring extensive grasslands. The time-consuming requirement to collect concurrent field data for each image implies a need to share the high fixed costs of processing an image across multiple users.

\section{Experimental Use of Remote Sensing by Private Range Managers and Its Influence on Management Decisions}

\section{H. Scott Butterfield and Carolyn M. Malmstrom}

We examined what characteristics of private range managers and their properties encourage the use of remote sensing data and its influence on managers' decision making. Using surveys of managers participating in a rangeland restoration program and case study analyses, we found that remote sensing data was most likely to be invested in by managers who believed that its inclusion could help address difficult management situations and increase ranch profitability. Our study demonstrates that collaborations between scientists and managers can increase the number of managers exposed to these technologies and also their applicability for and impact on conservation efforts on private rangelands.

\section{Establishing Vegetation on Migrating Inland} Sand Dunes in Texas

Timothy E. Fulbright, J. Alfonso Ortega-Santos, Alejandro Lozano-Cavazos, and Luis Enrique Ramírez-Yanez

Migrating sand dunes in the Coastal Sand Plain of southern Texas may damage or cover range improvements. We determined effectiveness of 2 types of mulches, seeding, fertilization, and plant transplanting in establishing vegetation on inland sand dunes. These treatments had little effect on canopy cover and plant species composition of the dunes in 2004, 10 years after the treatments were established. Mulching to prevent sand movement appears to be the only treatment necessary for vegetation to establish on dunes in the Coastal Sand Plain under the environmental conditions prevailing during our study.

\section{Use of Fluorometry to Differentiate Among Clipped Species in the Genera Astragalus, Oxytropis, and Pleuraphis \\ Dean M. Anderson, Gary D. Rayson, Safwan M. Obeidat, Michael Ralphs, Rick Estell, Ed L. Fredrickson, Eric Parker, and Perry Gray}

The rapid and accurate determination of what plants constitute an animal's diet remains a challenge. Current techniques are labor intensive, and the data are often available only after extended analysis and interpretation, adding to the cost of management. An optical-based methodology termed fluorometry, when combined with principal component analysis (PCA), appears to be a promising tool for determining the presence of individual plant species composing an animal's diet. These data on clipped plants, some of which were considered toxic to free-ranging animals, suggest that fluorometry may provide a robust methodology for differentiating between toxic and nontoxic plants. 